\title{
Quality Matters: Systematic Analysis of Endpoints Related to "Cellular Life" in Vitro Data of Radiofrequency Electromagnetic Field Exposure
}

\author{
Myrtill Simkó ${ }^{1, *}$, Daniel Remondini ${ }^{2}$, Olga Zeni ${ }^{3}$ and Maria Rosaria Scarfi ${ }^{3}$ \\ 1 Environmental Resources and Technologies, Department Health and Environment, \\ AIT Austrian Institute of Technology, Tulln 3430, Austria \\ 2 Dipartimento di Fisica e Astronomia, Università di Bologna, Bologna 40126, Italy; daniel.remondini@unibo.it \\ 3 CNR-Institute for Electromagnetic Sensing of the Environment, Napoli 80124, Italy; zeni.o@irea.cnr.it (O.Z.); \\ scarfi.mr@irea.cnr.it (M.R.S.) \\ * Correspondence: myrtill.simko@ait.ac.at; Tel.: +43-664-235-1774
}

Academic Editor: Irena Cosic

Received: 14 June 2016; Accepted: 5 July 2016; Published: 12 July 2016

\begin{abstract}
Possible hazardous effects of radiofrequency electromagnetic fields (RF-EMF) at low exposure levels are controversially discussed due to inconsistent study findings. Therefore, the main focus of the present study is to detect if any statistical association exists between RF-EMF and cellular responses, considering cell proliferation and apoptosis endpoints separately and with both combined as a group of "cellular life" to increase the statistical power of the analysis. We searched for publications regarding RF-EMF in vitro studies in the PubMed database for the period 1995-2014 and extracted the data to the relevant parameters, such as cell culture type, frequency, exposure duration, SAR, and five exposure-related quality criteria. These parameters were used for an association study with the experimental outcome in terms of the defined endpoints. We identified 104 published articles, from which 483 different experiments were extracted and analyzed. Cellular responses after exposure to RF-EMF were significantly associated to cell lines rather than to primary cells. No other experimental parameter was significantly associated with cellular responses. A highly significant negative association with exposure condition-quality and cellular responses was detected, showing that the more the quality criteria requirements were satisfied, the smaller the number of detected cellular responses. According to our knowledge, this is the first systematic analysis of specific RF-EMF bio-effects in association to exposure quality, highlighting the need for more stringent quality procedures for the exposure conditions.
\end{abstract}

Keywords: apoptosis; cell proliferation; association analysis; electromagnetic fields; in vitro

\section{Introduction}

There are many national and international organizations, committees, and institutions performing health risk assessment regarding exposure to radiofrequency electromagnetic fields (RF-EMF) with various outcomes. Among them are the World Health Organization (WHO), the International Commission on Non-Ionizing Radiation Protection (ICNIRP), the International Agency for Research on Cancer (IARC), the Institute of Electrical and Electronic Engineers (IEEE), and the European Commission (SCENIHR, Scientific Committee for the Emerging and Newly Identified Health Risks). In a recent review [1], the different evaluations were summarized and analyzed with the general conclusion that more research is needed to get answers to health risk-related questions.

There is a vast amount of scientific literature regarding the biological effects of RF-EMF in in vitro and in vivo investigations, but many epidemiological studies have also been carried out with 
inconsistent results. In addition, many review articles have summarized the state of the art in almost all areas of biology, considering different living systems, exposure levels (specific absorption rates, SAR), frequencies, exposure duration, and so on (for some of the recent review articles, see [1-8]). The main concern regards possible biological effects at the non-thermal level of RF exposure. This is of fundamental relevance for everyday low-power applications of RF, such as cell phones, Wi-Fi connections, etc., which operate at power levels where tissue-heating (thermal) effects are not expected to occur. Although experimental studies have been performed for decades, there is still controversy on possible effects at these low exposure levels, especially since there is no convincing mechanistic explanation of a biological effect. In addition, there are no consistent findings supporting any adverse effects.

In vitro studies are the most common for the evaluation of biological effects of RF-EMF. They are carried out on tissue or cell cultures of animal or human origin, on transformed or primary cells and cell lines. Moreover, they are relatively simple to handle and represent well-described in models, where the control of experimental conditions, including exposure, is significantly better than in vivo animal or human studies.

Cell proliferation and apoptosis-in vitro processes that are studied for cellular responses of RF-EMF exposure-are among the most investigated. They are fundamental processes in multicellular organisms and are tightly connected to each other. Cell proliferation is an increase in cell number, and may result from increased growth and division or from decreased cell death. Cell proliferation can be stimulated by physiological and pathological conditions and is largely controlled (stimulated or inhibited) by signals from the microenvironment. An excess of stimulators or a deficiency of inhibitors leads to net growth and, in the case of cancer, uncontrolled growth.

Apoptosis is a physiological process essential for balanced tissue homeostasis and is thus part of cell growth. There are several lines of evidence linking apoptosis to proliferation (see [9]). Nevertheless, apoptosis can also be induced by a variety of pathological stimuli. Apoptosis can be triggered by intracellular or extracellular signals which follow two main pathways: the intrinsic or mitochondrial pathway, which transmits intracellular received death signals, and the extrinsic or death receptor pathway, relaying apoptotic messages via receptors.

Here we chose to analyze investigations related to cell proliferation and apoptosis, considered both separately and combined into a group of "cellular life". The main goal of this study is the use of the "grouping approach" to experimental parameters [10], and thus to test if any statistical association exists between RF-EMF and cellular responses. Furthermore, we define five criteria to analyze the quality of the exposure conditions within the selected studies. We think that this approach enables a more comprehensive analysis of available data to detect an association between cellular response(s) and RF-EMF exposure parameters. Moreover, this data evaluation allows an independent and unbiased execution of the analysis, which can contribute to a better understanding of RF-EMF exposure and cellular response(s).

\section{Materials and Methods}

\subsection{Literature Search}

A literature search was conducted by using the PubMed (www.ncbi.nlm.nih.gov/pubmed) bibliographic database. Keywords used for the exposure element of the studies were: electromagnetic fields, microwaves, radio waves, nonionizing, radiofrequency, cellular phone, mobile phone, base station, GSM, UMTS, and mobile communication. For the outcome elements, the following key words were used: apoptosis, programmed cell death, annexin, tunel, phosphatidylserine, mitochondrial pathway, death receptor, chromatin condensation, caspase, caspase cleavage, cell cycle, cell cycle progression, cyclins, and cell proliferation. Peer reviewed original articles from 1995 to 2014 in the English language were considered, whereas review articles were disregarded. 
All identified investigations, with the exception of whole genomic or proteomic studies, were included in the analysis. Consequently, no exclusion criteria (regarding exposure conditions) were applied. Since in several cases a paper reported more than one tested experimental condition (e.g., due to a different exposure duration or SAR), all different experimental results were extracted and analyzed.

\subsection{Data Extraction}

A spread-sheet document was built up to assist data extraction from all the experiments recognized. For each experiment we recorded the following information: bibliographic reference, cell culture type (considering primary cells and cell lines, in the following referred to as "cell type"), investigated endpoints (apoptosis or cell proliferation), outcome (cellular response/no response, whereby "response" is referred to if the paper reported a statistically significant $(p<0.05)$ outcome in comparison to the respective control, independently of the direction), exposure frequency, duration, and SAR value. Furthermore, we collected data about frequency modulation, co-exposure(s), and statistical power. As "quality criteria" we defined the presence of sham-exposure, appropriate dosimetry, use of positive control, blinded analysis, and temperature control.

\subsection{Data Analysis}

First, we performed descriptive statistics of the selected parameters in order to characterize the publications both over time (i.e., in the period from 1995 to 2014) and by cell type (primary cells or cell lines). Secondly, we tested the hypothesis that the outcomes of the experiments could be significantly associated to specific factors such as biological endpoint, cell type, exposure frequency, exposure duration, and SAR. Regarding biological endpoints, apoptosis, cell proliferation, and both combined as a group of "cellular life" were considered, while cell type was categorized as primary cells and cell lines. For the frequency variable, the intervals considered were: $0.5-1 \mathrm{GHz}, 1-3 \mathrm{GHz}, 3-10 \mathrm{GHz}$, and $>10 \mathrm{GHz}$. These intervals were chosen in accordance with the frequency intervals of the most common RF-EMF appliances.

Intervals for the exposure duration were chosen as acute ( $\leqslant 60 \mathrm{~min})$, long $(1-24 \mathrm{~h})$, and chronic (day/s) exposure, whereby the latter group includes those experiments that used intermittent exposure over several days.

Finally, the SAR values were pooled into three groups ( $\leqslant 1 \mathrm{~W} / \mathrm{kg}, 1-2 \mathrm{~W} / \mathrm{kg}$, $>2 \mathrm{~W} / \mathrm{kg}$ ) with regard to under, around, and above the safety limits [6]. The variables and group ranges are reported in Table 1. Furthermore, the quality of the performed studies was also taken into account. We considered the highest quality criteria (labelled as Q5) when an experiment satisfied all five quality controls: sham, dosimetry control, temperature control, blinded manner, and positive control. Experiments labelled Q4 to Q1 refer to those in which four to one quality criteria were satisfied. We did not rank these criteria. However, we also tested the specific association of the experimental outcome with sham and dosimetry, or sham, dosimetry, and temperature, as specific cases of Q2 and Q3, respectively, since these criteria are often mentioned in the literature as the most relevant, and also because these were the most present criteria [11-15].

Table 1. Variables and group ranges of selected parameters.

\begin{tabular}{ccccc}
\hline Biological Endpoint & Cell Type & Frequency & Exposure Duration & SAR \\
\hline apoptosis & primary cells & $0.5-1 \mathrm{GHz}$ & acute $(\leqslant 60 \mathrm{~min})$ & $\leqslant 1 \mathrm{~W} / \mathrm{kg}$ \\
cell proliferation & cell lines & $1-3 \mathrm{GHz}$ & long $(1-24 \mathrm{~h})$ & $1-2 \mathrm{~W} / \mathrm{kg}$ \\
"cellular life" & & $3-10 \mathrm{GHZ}$ & chronic (day $/ \mathrm{s})$ & $>2 \mathrm{~W} / \mathrm{kg}$ \\
& & $>10 \mathrm{GHz}$ & & \\
\hline
\end{tabular}

SAR: Specific Absorption Rate.

We performed a Fisher exact test (Mathworks Matlab software) for the association of each selected variable with the experimental outcome (no response/response). In cases in which the variable 
was classified into more than two intervals (e.g., exposure frequency), each interval was tested for association with the outcome in comparison with all the remaining groups. Furthermore, for the quality criteria variables, we performed an association test for each variable-namely, the presence of a minimum number (from 1 to 5 ) of satisfied quality criteria against the experiments with a smaller number of satisfied criteria. We defined a significance threshold $p=0.05$ for our analyses.

\section{Results}

We identified 104 peer-reviewed publications, and extracted 483 different experimental results dealing with apoptosis or cell cycle/proliferation (Table 2 and Supplementary Material Table S1 including all information). All responses were considered separately, independently of the size or direction of the response but considering the given $p<0.05$, as described in the related paper. We did not consider whole genomic or proteomic studies, since in these cases the responses are too complex to be condensed in a response/no response dichotomy.

Table 2. Identified publications and number of experiments.

\begin{tabular}{cccccccc}
\hline Reference & $\begin{array}{c}\text { Number of } \\
\text { Experiments }\end{array}$ & Reference & $\begin{array}{c}\text { Number of } \\
\text { Experiments }\end{array}$ & Reference & $\begin{array}{c}\text { Number of } \\
\text { Experiments }\end{array}$ & Reference & $\begin{array}{c}\text { Number of } \\
\text { Experiments }\end{array}$ \\
\hline$[16]$ & 15 & {$[17]$} & 2 & {$[18]$} & 4 & {$[19]$} & 4 \\
{$[20]$} & 18 & {$[21]$} & 2 & {$[22]$} & 3 & {$[23]$} & 2 \\
{$[24]$} & 2 & {$[25]$} & 3 & {$[26]$} & 4 & {$[27]$} & 2 \\
{$[28]$} & 4 & {$[29]$} & 6 & {$[30]$} & 2 & {$[31]$} & 6 \\
{$[32]$} & 1 & {$[33]$} & 2 & {$[34]$} & 4 & {$[35]$} & 1 \\
{$[36]$} & 1 & {$[37]$} & 8 & {$[38]$} & 3 & {$[39]$} & 2 \\
{$[40]$} & 1 & {$[41]$} & 2 & {$[42]$} & 4 & {$[43]$} & 1 \\
{$[44]$} & 1 & {$[45]$} & 4 & {$[46]$} & 2 & {$[47]$} & 7 \\
{$[48]$} & 2 & {$[49]$} & 1 & {$[50]$} & 2 & {$[51]$} & 10 \\
{$[52]$} & 2 & {$[53]$} & 3 & {$[54]$} & 4 & {$[55]$} & 2 \\
{$[56]$} & 2 & {$[57]$} & 1 & {$[58]$} & 6 & {$[59]$} & 1 \\
{$[60]$} & 4 & {$[61]$} & 2 & {$[62]$} & 9 & {$[63]$} & 7 \\
{$[64]$} & 2 & {$[65]$} & 3 & {$[66]$} & 10 & {$[67]$} & 4 \\
{$[68]$} & 1 & {$[69]$} & 3 & {$[70]$} & 2 & {$[71]$} & 2 \\
{$[72]$} & 11 & {$[73]$} & 1 & {$[74]$} & 36 & {$[75]$} & 7 \\
{$[76]$} & 1 & {$[77]$} & 12 & {$[78]$} & 4 & {$[79]$} & 13 \\
{$[80]$} & 1 & {$[81]$} & 12 & {$[82]$} & 3 & {$[83]$} & 10 \\
{$[84]$} & 4 & {$[85]$} & 5 & {$[86]$} & 2 & {$[87]$} & 2 \\
{$[88]$} & 1 & {$[89]$} & 2 & {$[90]$} & 4 & {$[91]$} & 2 \\
{$[92]$} & 1 & {$[93]$} & 2 & {$[94]$} & 10 & {$[95]$} & 2 \\
{$[96]$} & 2 & {$[97]$} & 6 & {$[98]$} & 2 & {$[99]$} & 2 \\
{$[100]$} & 2 & {$[101]$} & 4 & {$[102]$} & 8 & {$[103]$} & 1 \\
{$[104]$} & 2 & {$[105]$} & 4 & {$[106]$} & 3 & {$[107]$} & 3 \\
{$[108]$} & 4 & {$[109]$} & 4 & {$[110]$} & 1 & {$[111]$} & 14 \\
{$[112]$} & 8 & {$[113]$} & 12 & {$[114]$} & 12 & {$[115]$} & 16 \\
{$[116]$} & 3 & {$[117]$} & 8 & {$[118]$} & 1 & {$[119]$} & 5 \\
\hline
\end{tabular}

The identified experiments were carried out on 28 different primary cell types (188 experiments) and 46 different cell lines (295 experiments) (Figure 1). The "cellular life" group resulted in 105 cellular responses out of 483 total experiments $(22 \%)$. The Fisher test detected a significant correlation between cellular responses on "cellular life" and cell lines, as compared to primary cells $(p=0.016)$. In other words, it is more likely that cellular responses regarding this outcome appear in cell lines than in primary cells (Figure 1a).

Apoptosis was affected in 44 cases among 137 (32\%), while proliferation was affected in 61 experiments among $346(18 \%)$, with a significant association of responses to apoptosis versus proliferation ( $p=0.0005$, Figure $1 b)$.

No association between any biological endpoint and frequency group was detected $(0.5-1 \mathrm{GHz}$, 214 experiments; 1-3 GHz, 237 experiments; 3-10 GHz, 13 experiments; >10 GHz, 19 experiments). We noticed 12 different modulations within the performed experiments. However, because of the 
small number of experiments for each modulation scheme, the analysis showed a very weak statistical power. Thus, this part of the analysis was not feasible.
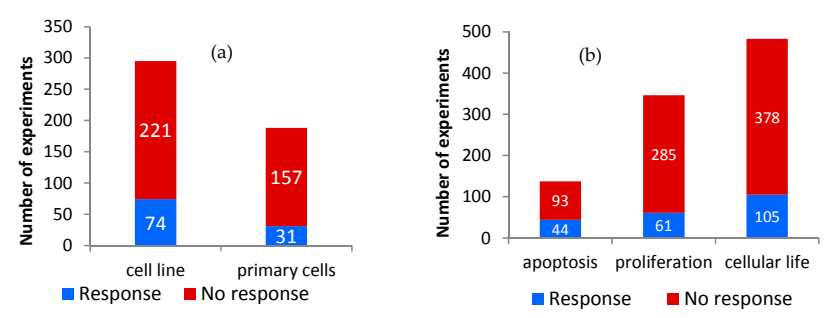

Figure 1. Cellular response in the different groups considered in the analysis: Number of experiments resulting in response or no response for (a) "cellular life" endpoint stratified by cell type; and (b) apoptosis and proliferation separately and combined in "cellular life" endpoint.

Exposure duration was grouped as acute ( $\leqslant 60 \mathrm{~min}, 77$ experiments), long (1-24 h, 253 experiments) and chronic ( $>24 \mathrm{~h}, 153$ experiments). No correlation between exposure duration and cellular response was detected. The association test with SAR level was carried out on experiments in which the SAR value was given in the publication; thus, only 404 experiments were considered ( 210 for SAR $<1 \mathrm{~W} / \mathrm{kg}$; 78 for $1-2 \mathrm{~W} / \mathrm{kg}$; and 116 for SAR $>2 \mathrm{~W} / \mathrm{kg}$ ). In addition, in this case, no association was detected (all association tests for frequency, exposure duration, and SAR intervals are listed in the Supplementary Material Table S2). An overview of the data extracted from all experiments is given in Figure 2, where the outcomes are reported for all groups considered.

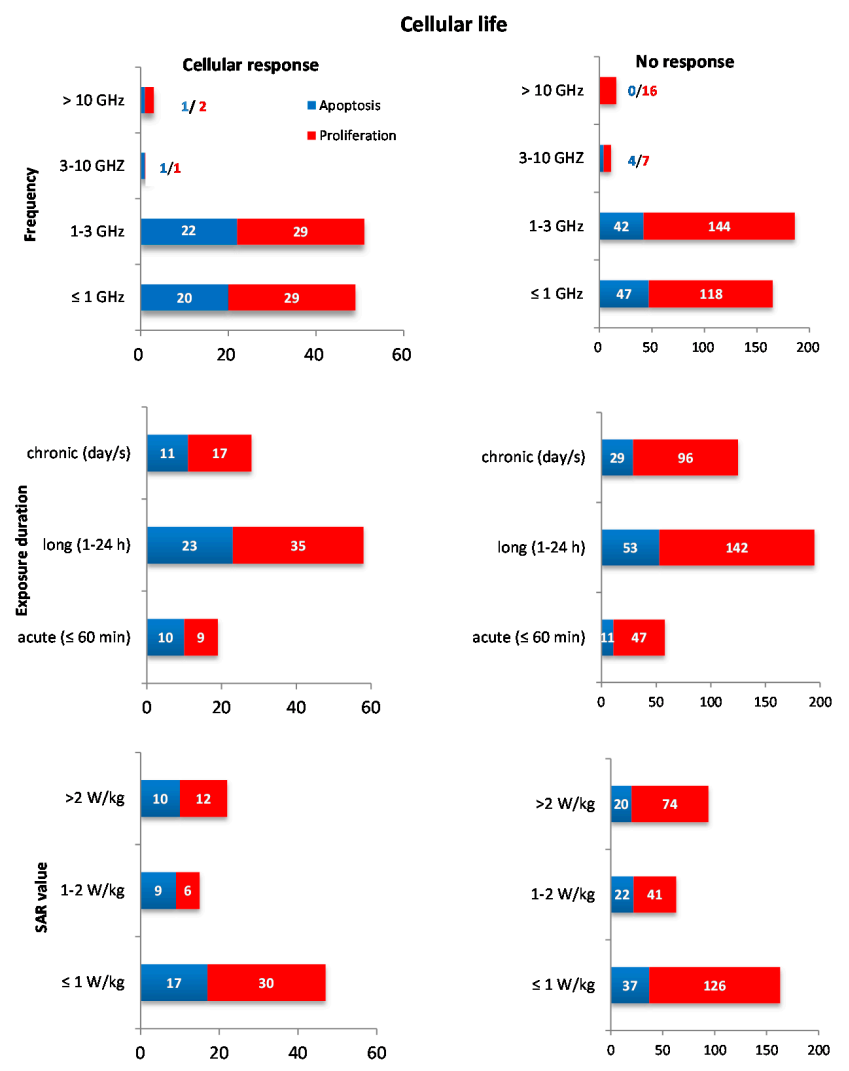

Figure 2. Compilation of data: The bar charts describe the number of experiments reporting cellular responses (left panel) and no responses (right panel) for "cellular life", stratified by apoptosis (blue) and cell proliferation (red) endpoints, and stratified into specific groups for frequency, exposure duration, and SAR value. 
The exposure quality was evaluated for all experiments in association to the "cellular life" group, according to the five selected criteria: sham (RF-control without RF exposure), dosimetry control, temperature control, blinded manner, and positive control. Sham exposure was used in 361 experiments, 347 experiments included numerical and/or experimental dosimetry, 404 included temperature control, 211 were performed in a blinded manner, and 179 included positive controls (Figure 3). There were 51 experiments using none of the mentioned quality criteria (Q0, 11\%), about $23 \%$ (109 experiments) satisfied all the quality criteria, and about $67 \%$ (323 experiments) satisfy from one to four criteria (Figure 3).
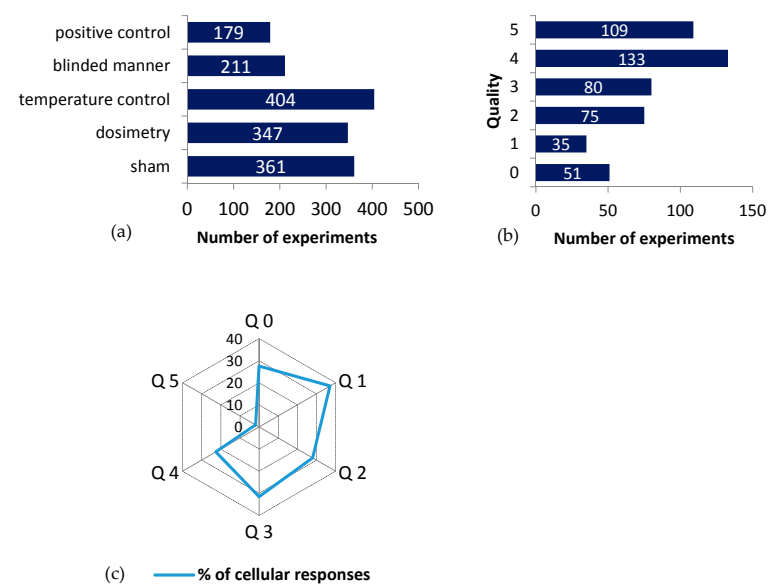

Figure 3. The quality of data: (a) The bar chart of the experiments that satisfied the listed quality criteria (y axis); (b) Experiments that satisfied a given number of quality criteria out of a total of 483 experiments; (c) Spider net plot of the percentage of cellular responses as a function of the quality of the experiments. Quality ranges from 0 (no criteria satisfied, Q0) to 5 (all criteria satisfied, Q5).

The ratio of cellular responses to RF-EMF exposure is between $22 \%$ and $37 \%$ in all experiments, in which no or parts of the quality criteria are satisfied (Q0-Q4, see Figure 3c). The Q5 group has less than $2 \%$ cellular responses (2 experiments out of 109). Fisher test for the Q5 group showed a strongly significant association between no responses and high-quality exposure conditions $\left(p=10^{-10}\right)$.

In addition, the other association studies related to quality (i.e., the Q1-Q4 cases, the Sham+Dosimetry, or the Sham + Dosimetry + Temperature cases) produced similar results-namely, in all cases, a smaller number of cellular responses was found for higher-quality experiments $\left(p<10^{-5}\right.$, see Table 3). The data show that the lower the quality criteria of the exposure condition, the more cellular responses are detected, with a large drop in responses for experiments in which all quality criteria are satisfied.

Table 3. Statistics for the association of quality scores with radiofrequency electromagnetic fields (RF-EMF) response.

\begin{tabular}{cccc}
\hline Quality Score $^{\mathbf{a}}$ & High-Q (\%) & Low-Q (\%) & $\boldsymbol{p ~ v a l u e ~}^{\mathbf{d}}$ \\
\hline 1 & 21.1 & 27.5 & 0.19 \\
2 & 19.6 & 31.4 & 0.014 \\
3 & 17.7 & 29.8 & 0.002 \\
4 & 13.2 & 30.3 & $4 \times 10^{-6}$ \\
5 & 1.8 & 27.5 & $4 \times 10^{-11}$ \\
S + D & 15.5 & 34.2 & $4 \times 10^{-6}$ \\
S + D + T & 16.1 & 31.8 & $6 \times 10^{-5}$ \\
\hline
\end{tabular}

a "Quality Score" column defines the range for the high-quality class (the number of criteria to be satisfied); b "S

$+\mathrm{D}$ " defines the experiments in which at least the Sham and the Dosimetry quality criteria are satisfied; " "S + D

$+T^{\prime \prime}$ defines the experiments with at least Sham, Dosimetry, and Temperature criteria are satisfied; ${ }^{d} p$ values describe significant association between cellular response and lower-quality experiments. 
As a descriptive analysis, the trend of the average exposure quality level over time for the considered experiments is presented in Figure 4. It appears that between 2005 and 2009, the overall number of experiments peaked (perhaps related to the scientific and public concern about cell-phone usage that was rapidly expanding in those years), with an average quality of around Q3 (three quality criteria satisfied). The number of studies has declined over the last five years of our survey period, accompanied by a small but significant increase of the average quality criteria to 3.5. A significant difference between the average quality of the studies before and after 2005 was detected $\left(p=10^{-5}\right)$.

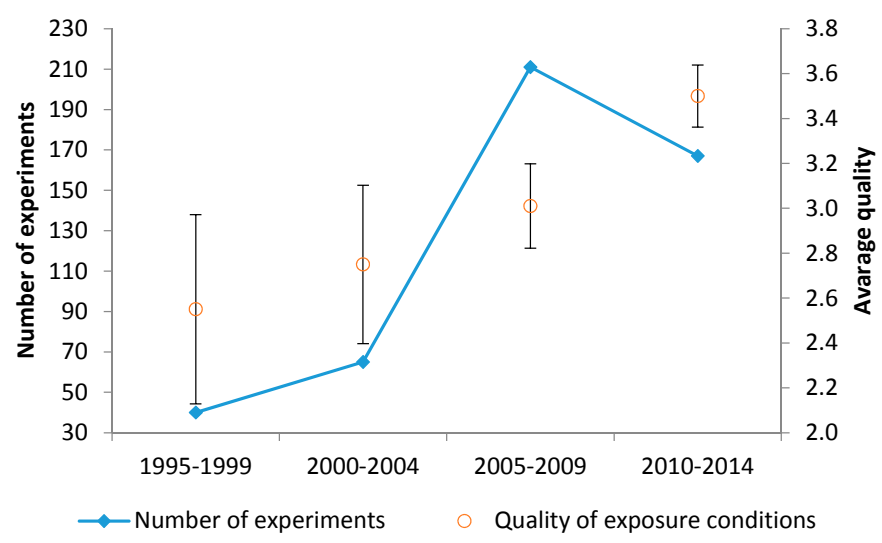

Figure 4. Average quality level of the experiments over the years: Number of experiments from 1995 to 2014 (with five-year intervals) (left y-axis) in parallel to the average quality score of the experiments (right y-axis).

\section{Discussion}

The possible effect of exposure to non-thermal RF-EMF, where the exposure is not causing any tissue heating, causes controversies. A common concern is about the possible long-term health effects of exposure at very low (below tissue heating) levels. In 2013, an expert group of the International Agency for Research on Cancer [5] classified RF-EMF as a possible carcinogen for humans (risk group 2B) since there is "limited evidence" for the carcinogenicity, based on positive associations in epidemiological studies between glioma and acoustic neuroma and exposure to RF-EMF. More recently, epidemiological studies have not confirmed any correlation between RF-EMF exposure and disease development (for a review see [8]). Furthermore, there are no experimental findings that can provide a mechanistic explanation for such an outcome, thus no established biological or biophysical mechanism of action exists so far.

The majority of the studies regarding effects of RF-exposure available in the literature refer to in vitro investigations, due to their key role in advancing knowledge about the possible relationship between RF exposures and human diseases. These studies display inconsistent results, possibly due to differences in the used cell type, frequency, SAR value, exposure duration, and observed cellular endpoint(s). Thus, the question of whether non-thermal RF exposure can alter cellular function in vitro still remains unresolved. Therefore, in the present study, we aimed to analyze specific in vitro data by using a statistical non-biased method to see if there is any association between positive findings and RF-EMF exposure. We chose the period from 1995 to 2014 since in this period the overall use of mobile telephones and wireless communication dramatically increased worldwide. In particular, we focused on apoptosis and cell proliferation, which are two major cellular processes that have been frequently investigated in RF-EMF related in vitro studies. Here we addressed all available published data in cellular and molecular investigations without applying any exclusion criteria, but not considering whole proteomic and genomic studies. Both endpoints were analyzed separately, and also combined in a group of "cellular life", improving the statistical power of the analysis. For the same reason, the extracted experiments were pooled into specific groups and intervals (cell type, frequency, exposure 
duration, and SAR value) in order to see if there is any statistical association of cellular responses with one or more of these categories. For our purposes, the statistically significant $(p<0.05)$ biological effect observed in the related publication, independent of the direction of the outcome, was considered as a cellular response.

Our analysis showed both cellular responses and no responses, where cellular responses were significantly associated with apoptosis rather than with cell proliferation, with more experiments focusing on proliferation (346) than on apoptosis (137). We also detected a higher association of cellular responses with cell lines (295) rather than with primary cells (188). At the present stage, we have no explanation for this association. There seems to be an imbalance in the numbers of specific investigations; however, the outcome of the test should not be affected by that.

The grouped experiments for frequency, exposure duration, and SAR values did not produce any statistical association with cellular responses including high SAR values $(>2 \mathrm{~W} / \mathrm{kg})$ and chronic exposure duration $(\geqslant 24 \mathrm{~h}$ ); however, according to experiments from "classical" toxicological studies, one could otherwise expect that higher exposure levels and longer exposure duration would foster cellular responses.

Data were not grouped and analyzed for modulation scheme, since no associations between frequency and cellular responses were detected. Moreover, the scanty number of experiments for each of the twelve modulation schemes identified would have led to unreliable results due to the weak statistical power.

In vitro experiments which aim to study cellular response(s) of RF-EMF exposure need specific experimental controls to reduce confounding variables. These variables could otherwise affect the results and impair reliability and reproducibility of the experiments. On the basis of the suggestions from the World Health Organization (WHO) in the EMF Project [120] and of published general guidelines for RF in vitro exposure setups [11-15], we considered five relevant quality criteria for RF exposure of cell cultures (temperature control, dosimetry, sham, positive control, and blinded experimental condition). We want to stress that these criteria were not ranked, since we considered all of them equally relevant for good laboratory practices. In detail, since it is known that certain RF-EMF setups induce a temperature increase within the exposed cell culture dishes, and thus may cause false positive cellular responses, temperature must be monitored by using non-perturbing probes and active cooling with either forced air or water. SAR $(\mathrm{W} / \mathrm{kg})$ is a measure of the absorbed energy rate by the human body/tissue exposed to RF-EMF, and is widely used for the international regulation of protection against electromagnetic fields. Furthermore, it is suitable to use this parameter to compare biological effects observed under different exposure conditions. Monitoring the SAR distribution pattern by means of numerical and/or empirical analysis within the cell cultures, is of paramount importance and allows the avoidance of undesired "hot spots" that can cause local heating within the sample. The sham control sample (cell culture placed in a RF exposure device identical to the one employed for the exposure but with zero RF) represents the true control, taking into account the microenvironment in the exposure device and the experimental conditions that could affect the cellular endpoint under examination. Positive controls provide evidence for controlled experimental conditions, assuring that the assay methodology is responding adequately to a well-known agent. Moreover, performing experiments in a blind manner, with samples coded so that their treatment group is unknown until the data are analyzed, will allow for the prevention of any kind of bias in data analysis. This is particularly relevant, especially when a slight variation is expected, as it is for RF exposure.

By introducing the five above-mentioned quality criteria, all identified cellular responses were tested for association, grouped as (Q0), Q1 to Q5 according to the number of satisfied criteria. Interestingly, the lower the quality of the exposure condition, the more responses were detected. This was true even when three specific exposure criteria were considered-namely, temperature, sham exposure, and dosimetry. In particular, when moving from Q1 to Q5, we observed an increasing negative association of the responses and number of satisfied criteria, with a significant drop in cellular 
responses for Q5. When all quality criteria were satisfied, only two experiments of 109 showed cellular responses, against an average response of about $27 \%$ for the Q1-Q4 cases. These findings further highlight the importance of performing experiments under strictly-controlled exposure conditions, in order to clarify the conflicting results reported in the literature. Only 109 experiments out of $483(<25 \%)$ in the period of 1995-2014 satisfied the highest quality denominator Q5. Here we have observed that, when comparing the literature from the last five years with the preceding period, the average quality has significantly increased from 3 to 3.5 (Figure 4) with 105 Q5 records in the most recent decade, but it is still very far from an optimal control of experimental procedures (they correspond to less than $30 \%$ of the total record of the decade).

\section{Conclusions}

Taking it together, our analysis shows that in vitro cellular response after exposure to RF-EMF-Considering apoptosis and cell proliferation separately and both combined in a group of "cellular life" - have no significant association to any of the relevant exposure parameters, such as frequency, exposure duration, or SAR value. Only cell lines showed a statistically significant higher association with cellular response, as compared to primary cell cultures. The most relevant result in the present study is the negative association between outcomes of cellular responses and the quality of the experimental procedures, specifically to the exposure conditions. The more the quality criteria requirements were satisfied, the smaller the number of cellular responses that were detected, with a dramatic drop in the number of responses at the highest possible quality criteria number $(<2 \%$ in more than 100 experiments).

Our study provides evidence that the accurate control of the exposure and experimental procedures is crucial. Therefore, we suggest the definition of an appropriate Standard Operating Procedure (SOP) for EMF research (at least for the investigation of non-thermal RF-EMF effects) or a rigorous definition of a unified "best practice", such as the MIAME procedure for gene expression microarray experiments [121].

We think that our analysis provides robust results investigating the association of several RF-EMF experimental conditions to selected biological endpoints. Moreover, the results shows that improving the experimental quality by means of appropriate procedural protocols might allow addressing controversies in EMF research more clearly.

Supplementary Materials: The following are available online at www.mdpi.com/1660-4601/13/7/701/s1, Table S1: List of selected publications and extracted experiments related to apoptosis and cell proliferation after exposure to RF-EMF, Table S2: Association test for exposure frequency, duration and SAR intervals.

Acknowledgments: This work was partly supported by the Swiss Research Foundation on Electricity and Mobile Communication (FSM) with the project No. B2014-04 (Grant to MS).

Author Contributions: All authors (Myrtill Simkó, Daniel Remondini, Olga Zeni and Maria Rosaria Scarfi) contributed equally to this work, meaning that all authors performed literature search, data extraction, discussions about the data analysis and writing the manuscript.

Conflicts of Interest: The authors declare no conflict of interest. The founding sponsors had no role in the design of the study; in the collection, analyses, or interpretation of data; in the writing of the manuscript, and in the decision to publish the results.

\section{References}

1. Vijayalaxmi; Scarfi, M.R. International and national expert group evaluations: Biological/health effects of radiofrequency fields. Int. J. Environ. Res. Public Health 2014, 11, 9376-9408. [CrossRef] [PubMed]

2. Gherardini, L.; Ciuti, G.; Tognarelli, S.; Cinti, C. Searching for the perfect wave: The effect of radiofrequency electromagnetic fields on cells. Int. J. Mol. Sci. 2014, 15, 5366-5387. [CrossRef] [PubMed]

3. Le Cann, P.; Bonvallot, N.; Glorennec, P.; Deguen, S.; Goeury, C.; Le Bot, B. Indoor environment and children's health: Recent developments in chemical, biological, physical and social aspects. Int. J. Hyg. Environ. Health 2011, 215, 1-18. [CrossRef] [PubMed] 
4. Marjanovic, A.M.; Pavicic, I.; Trosic, I. Biological indicators in response to radiofrequency/microwave exposure. Arch. Hig. Rada Toksikol. 2012, 63, 407-416. [CrossRef] [PubMed]

5. IARC. Non-ionizing radiation, Part 2: Radiofrequency electromagnetic fields. IARC Monogr. Eval. Carcinog. Risks Hum. 2013, 102, 1-460.

6. ICNIRP. Guidelines for limiting exposure to time-varying electric and magnetic fields (1 Hz to $100 \mathrm{KHz})$. Health Phys. 2010, 99, 818-836.

7. SCENIHR. Health Effects of Exposure to EMF. Available online: http://ec.europa.eu/health/archive/ph_ risk/committees/04_scenihr/docs/scenihr_o_022.pdf (accessed on 25 May 2016).

8. SCENIHR. Opinion on potential health effects of exposure to electromagnetic fields. Bioelectromagnetics 2015, $36,480-484$.

9. Shen, T.; Huang, S. The role of Cdc25A in the regulation of cell proliferation and apoptosis. Anticancer Agents. Med. Chem. 2012, 12, 631-639. [CrossRef] [PubMed]

10. Mattsson, M.-O.; Simkó, M. Grouping of experimental conditions as an approach to evaluate effects of extremely low frequency magnetic fields on oxidative response in in vitro studies. Front. Public Health 2014, 2, 132. [CrossRef] [PubMed]

11. Schuderer, R.; Spat, D.; Samaras, T.; Oesch, W.; Kuster, N. In vitro exposure systems for RF exposures at 900 MHz. IEEE Trans. Microwave Theory Tech. 2004, 52, 2067-2075. [CrossRef]

12. Paffi, A.; Apollonio, F.; Lovisolo, G.A.; Marino, C.; Pinto, R.; Repacholi, M.; Liberti, M. Considerations for developing an RF exposure system: A review for in vitro biological experiments. IEEE Trans. Microwave Theory Tech. 2010, 58, 2702-2714. [CrossRef]

13. Chou, C.K.; Bassen, H.; Osepchuk, J.; Balzano, Q.; Petersen, R.; Meltz, M.; Cleveland, R.; Lin, J.C.; Heynick, L. Radio frequency electromagnetic exposure: Tutorial review on experimental dosimetry. Bioelectromagnetics 1996, 17, 195-208. [CrossRef]

14. Kuster, N.; Schonborn, F. Recommended minimal requirements and development guidelines for exposure setups of bio-experiments addressing the health risk concern of wireless communications. Bioelectromagnetics 2000, 21, 508-514. [CrossRef]

15. Zeni, O.; Scarfi, M.R. Experimental requirements for in vitro studies aimed to evaluate the biological effects of radiofrequency radiation, microwave materials characterization. In Microwave Materials Characterization; Costanzo, S., Ed.; InTech: Rijeka, Croatia, 2012; pp. 121-138.

16. Antonopoulos, A.; Eisenbrandt, H.; Obe, G. Effects of high-frequency electromagnetic fields on human lymphocytes in vitro. Mutat. Res. 1997, 395, 209-214. [CrossRef]

17. Huang, T.Q.; Lee, M.S.; Oh, E.; Zhang, B.T.; Seo, J.S.; Park, W.Y. Molecular responses of Jurkat T-cells to 1763 $\mathrm{MHz}$ radiofrequency radiation. Int. J. Radiat. Biol. 2008, 84, 734-741. [CrossRef] [PubMed]

18. Palumbo, R.; Brescia, F.; Capasso, D.; Sannino, A.; Sarti, M.; Capri, M.; Grassilli, E.; Scarfi, M.R. Exposure to $900 \mathrm{MHz}$ radiofrequency radiation induces caspase 3 activation in proliferating human lymphocytes. Radiat. Res. 2008, 170, 327-334. [CrossRef] [PubMed]

19. Yoon, S.Y.; Kim, K.T.; Jo, S.J.; Cho, A.R.; Jeon, S.I.; Choi, H.D.; Kim, K.H.; Park, G.S.; Pack, J.K.; Kwon, O.S.; et al. Induction of hair growth by insulin-like growth factor-1 in $1763 \mathrm{MHz}$ radiofrequency-Irradiated hair follicle cells. PLOS ONE 2011. [CrossRef]

20. Atasoy, A.; Sevim, Y.; Kaya, I.; Yilmaz, M.; Durmus, A.; Sonmez, M.; Omay, S.B.; Ozdemir, F.; Ovali, E. The effects of electromagnetic fields on peripheral blood mononuclear cells in vitro. Bratisl. Lek. Listy. 2009, 110, 526-529. [PubMed]

21. Huang, T.Q.; Lee, M.S.; Oh, E.H.; Kalinec, F.; Zhang, B.T.; Seo, J.S.; Park, W.Y. Characterization of biological effect of $1763 \mathrm{MHz}$ radiofrequency exposure on auditory hair cells. Int. J. Radiat. Biol. 2008, 84, 909-915. [CrossRef] [PubMed]

22. Pavicic, I.; Trosic, I. Influence of $864 \mathrm{MHz}$ electromagnetic field on growth kinetics of established cell line. Biologia 2006, 61, 321-325. [CrossRef]

23. Avendano, C.; Mata, A.; Sanchez Sarmiento, C.A.; Doncel, G.F. Use of laptop computers connected to internet through Wi-Fi decreases human sperm motility and increases sperm DNA fragmentation. Fertil. Steril. 2012. [CrossRef] [PubMed]

24. Jin, Z.; Zong, C.; Jiang, B.; Zhou, Z.; Tong, J.; Cao, Y. The effect of combined exposure of $900 \mathrm{MHz}$ radiofrequency fields and doxorubicin in HL-60 cells. PLoS ONE 2012. [CrossRef] [PubMed] 
25. Pavicic, I.; Trosic, I. In vitro testing of cellular response to ultra high frequency electromagnetic field radiation. Toxicol. In Vitro 2008, 22, 1344-1348. [CrossRef] [PubMed]

26. Zeni, O.; Chiavoni, A.S.; Sannino, A.; Antolini, A.; Forigo, D.; Bersani, F.; Scarfi, M.R. Lack of genotoxic effects (micronucleus induction) in human lymphocytes exposed in vitro to $900 \mathrm{MHz}$ electromagnetic fields. Radiat. Res. 2003, 160, 152-158. [CrossRef] [PubMed]

27. Belyaev, I.Y.; Hillert, L.; Protopopova, M.; Tamm, C.; Malmgren, L.O.; Persson, B.R.; Selivanova, G.; Harms-Ringdahl, M. $915 \mathrm{MHz}$ microwaves and $50 \mathrm{~Hz}$ magnetic field affect chromatin conformation and 53BP1 foci in human lymphocytes from hypersensitive and healthy persons. Bioelectromagnetics 2005, 26, 173-184. [CrossRef] [PubMed]

28. Joubert, V.; Leveque, P.; Rametti, A.; Collin, A.; Bourthoumieu, S.; Yardin, C. Microwave exposure of neuronal cells in vitro: Study of apoptosis. Int. J. Radiat. Biol. 2006, 82, 267-275. [CrossRef] [PubMed]

29. Pavicic, I.; Trosic, I. Impact of $864 \mathrm{MHz}$ or $935 \mathrm{MHz}$ radiofrequency microwave radiation on the basic growth parameters of V79 cell line. Acta Biol. Hung. 2008, 59, 67-76. [CrossRef] [PubMed]

30. Zeni, O.; Romano, M.; Perrotta, A.; Lioi, M.B.; Barbieri, R.; d'Ambrosio, G.; Massa, R.; Scarfi, M.R. Evaluation of genotoxic effects in human peripheral blood leukocytes following an acute in vitro exposure to $900 \mathrm{MHz}$ radiofrequency fields. Bioelectromagnetics 2005, 26, 258-265. [CrossRef] [PubMed]

31. Beneduci, A. Evaluation of the potential in vitro antiproliferative effects of millimeter waves at some therapeutic frequencies on RPMI 7932 human skin malignant melanoma cells. Cell. Biochem. Biophys. 2009, 55, 25-32. [CrossRef] [PubMed]

32. Joubert, V.; Leveque, P.; Cueille, M.; Bourthoumieu, S.; Yardin, C. No apoptosis is induced in rat cortical neurons exposed to GSM phone fields. Bioelectromagnetics 2007, 28, 115-121. [CrossRef] [PubMed]

33. Peinnequin, A.; Piriou, A.; Mathieu, J.; Dabouis, V.; Sebbah, C.; Malabiau, R.; Debouzy, J.C. Non-thermal effects of continuous $2.45 \mathrm{GHz}$ microwaves on fas-induced apoptosis in human jurkat T-cell line. Bioelectrochemistry 2000, 51, 157-161. [CrossRef]

34. Zeni, O.; Gallerano, G.P.; Perrotta, A.; Romano, M.; Sannino, A.; Sarti, M.; D’Arienzo, M.; Doria, A.; Giovenale, E.; Lai, A.; et al. Cytogenetic observations in human peripheral blood leukocytes following in vitro exposure to thz radiation: A pilot study. Health Phys. 2007, 92, 349-357. [CrossRef] [PubMed]

35. Beneduci, A.; Chidichimo, G.; De Rose, R.; Filippelli, L.; Straface, S.V.; Venuta, S. Frequency and irradiation time-dependant antiproliferative effect of low-power millimeter waves on RPMI 7932 human melanoma cell line. Anticancer Res. 2005, 25, 1023-1028. [PubMed]

36. Joubert, V.; Bourthoumieu, S.; Leveque, P.; Yardin, C. Apoptosis is induced by radiofrequency fields through the caspase-independent mitochondrial pathway in cortical neurons. Radiat. Res. 2008, 169, 38-45. [CrossRef] [PubMed]

37. Perez-Castejon, C.; Perez-Bruzon, R.N.; Llorente, M.; Pes, N.; Lacasa, C.; Figols, T.; Lahoz, M.; Maestu, C.; Vera-Gil, A.; Del Moral, A.; et al. Exposure to elf-pulse modulated x band microwaves increases in vitro human astrocytoma cell proliferation. Histol. Histopathol. 2009, 24, 1551-1561. [PubMed]

38. Zeni, O.; Schiavoni, A.; Perrotta, A.; Forigo, D.; Deplano, M.; Scarfi, M.R. Evaluation of genotoxic effects in human leukocytes after in vitro exposure to $1950 \mathrm{MHz}$ UMTS radiofrequency field. Bioelectromagnetics 2008, 29, 177-184. [CrossRef] [PubMed]

39. Beneduci, A.; Chidichimo, G.; Tripepi, S.; Perrotta, E.; Cufone, F. Antiproliferative effect of millimeter radiation on human erythromyeloid leukemia cell line K562 in culture: Ultrastructural- and metabolic-induced changes. Bioelectrochemistry 2007, 70, 214-220. [CrossRef] [PubMed]

40. Kahya, M.C.; Naziroglu, M.; Cig, B. Selenium reduces mobile phone (900 MHz)—Induced oxidative stress, mitochondrial function, and apoptosis in breast cancer cells. Biol. Trace Elem. Res. 2014, 160, 285-293. [CrossRef] [PubMed]

41. Port, M.; Abend, M.; Romer, B.; Van Beuningen, D. Influence of high-frequency electromagnetic fields on different modes of cell death and gene expression. Int. J. Radiat. Biol. 2003, 79, 701-708. [CrossRef] [PubMed]

42. Zeni, O.; Sannino, A.; Romeo, S.; Massa, R.; Sarti, M.; Reddy, A.B.; Prihoda, T.J.; Vijayalaxmi; Scarfi, M.R. Induction of an adaptive response in human blood lymphocytes exposed to radiofrequency fields: Influence of the universal mobile telecommunication system (UMTS) signal and the specific absorption rate. Mutat. Res. 2012, 747, 29-35. [CrossRef] [PubMed] 
43. Bock, J.; Fukuyo, Y.; Kang, S.; Phipps, M.L.; Alexandrov, L.B.; Rasmussen, K.O.; Bishop, A.R.; Rosen, E.D.; Martinez, J.S.; Chen, H.T.; et al. Mammalian stem cells reprogramming in response to terahertz radiation. PLoS ONE 2010. [CrossRef] [PubMed]

44. Karaca, E.; Durmaz, B.; Aktug, H.; Yildiz, T.; Guducu, C.; Irgi, M.; Koksal, M.G.; Ozkinay, F.; Gunduz, C.; Cogulu, O. The genotoxic effect of radiofrequency waves on mouse brain. J. Neurooncol. 2012, 106, 53-58. [CrossRef] [PubMed]

45. Sanchez, S.; Milochau, A.; Ruffie, G.; Poulletier de Gannes, F.; Lagroye, I.; Haro, E.; Surleve-Bazeille, J.E.; Billaudel, B.; Lassegues, M.; Veyret, B. Human skin cell stress response to GSM-900 mobile phone signals. In vitro study on isolated primary cells and reconstructed epidermis. FEBS J. 2006, 273, 5491-5507. [CrossRef] [PubMed]

46. Zeni, O.; Sannino, A.; Sarti, M.; Romeo, S.; Massa, R.; Scarfi, M.R. Radiofrequency radiation at $1950 \mathrm{MHz}$ (UMTS) does not affect key cellular endpoints in neuron-Like PC12 cells. Bioelectromagnetics 2012, 33, 497-507. [CrossRef] [PubMed]

47. Bourthoumieu, S.; Magnaudeix, A.; Terro, F.; Leveque, P.; Collin, A.; Yardin, C. Study of P53 expression and post-transcriptional modifications after GSM-900 radiofrequency exposure of human amniotic cells. Bioelectromagnetics 2013, 34, 52-60. [CrossRef] [PubMed]

48. Kumar, G.; Wood, A.W.; Anderson, V.; McIntosh, R.L.; Chen, Y.Y.; McKenzie, R.J. Evaluation of hematopoietic system effects after in vitro radiofrequency radiation exposure in rats. Int. J. Radiat. Biol. 2011, 87, 231-240. [CrossRef] [PubMed]

49. Sannino, A.; Di Costanzo, G.; Brescia, F.; Sarti, M.; Zeni, O.; Juutilainen, J.; Scarfi, M.R. Human fibroblasts and $900 \mathrm{MHz}$ radiofrequency radiation: Evaluation of DNA damage after exposure and co-exposure to 3-chloro-4-(dichloromethyl)-5-hydroxy-2(5h)-furanone (MX). Radiat. Res. 2009, 171, 743-751. [CrossRef] [PubMed]

50. Zhijian, C.; Xiaoxue, L.; Wei, Z.; Yezhen, L.; Jianlin, L.; Deqiang, L.; Shijie, C.; Lifen, J.; Jiliang, H. Studying the protein expression in human $B$ lymphoblastoid cells exposed to 1.8-GHz (GSM) radiofrequency radiation (RFR) with protein microarray. Biochem. Biophys. Res. Commun. 2013, 433, 36-39. [CrossRef] [PubMed]

51. Buttiglione, M.; Roca, L.; Montemurno, E.; Vitiello, F.; Capozzi, V.; Cibelli, G. Radiofrequency radiation (900 MHz) induces Egr-1 gene expression and affects cell-cycle control in human neuroblastoma cells. J. Cell. Physiol. 2007, 213, 759-767. [CrossRef] [PubMed]

52. Kwee, S.; Raskmark, P. Changes in cell proliferation due to environmental non-ionizing radiation: 2. Microwave radiation. Bioelectrochem. Bioenerg. 1998, 44, 251-255. [CrossRef]

53. Sannino, A.; Sarti, M.; Reddy, S.B.; Prihoda, T.J.; Vijayalaxmi; Scarfi, M.R. Induction of adaptive response in human blood lymphocytes exposed to radiofrequency radiation. Radiat. Res. 2009, 171, 735-742. [CrossRef] [PubMed]

54. Zotti-Martelli, L.; Peccatori, M.; Scarpato, R.; Migliore, L. Induction of micronuclei in human lymphocytes exposed in vitro to microwave radiation. Mutat. Res. 2000, 472, 51-58. [CrossRef]

55. Calabro, E.; Condello, S.; Curro, M.; Ferlazzo, N.; Caccamo, D.; Magazu, S.; Ientile, R. Modulation of heat shock protein response in SH-SY5Y by mobile phone microwaves. World J. Biol. Chem. 2012, 3, 34-40. [CrossRef] [PubMed]

56. Lantow, M.; Viergutz, T.; Weiss, D.G.; Simko, M. Comparative study of cell cycle kinetics and induction of apoptosis or necrosis after exposure of human Mono Mac 6 cells to radiofrequency radiation. Radiat. Res. 2006, 166, 539-543. [CrossRef] [PubMed]

57. Sannino, A.; Zeni, O.; Sarti, M.; Romeo, S.; Reddy, S.B.; Belisario, M.A.; Prihoda, T.J.; Vijayalaxmi; Scarfi, M.R. Induction of adaptive response in human blood lymphocytes exposed to $900 \mathrm{MHz}$ radiofrequency fields: Influence of cell cycle. Int. J. Radiat. Biol. 2011, 87, 993-999. [CrossRef] [PubMed]

58. Zotti-Martelli, L.; Peccatori, M.; Maggini, V.; Ballardin, M.; Barale, R. Individual responsiveness to induction of micronuclei in human lymphocytes after exposure in vitro to $1800-\mathrm{MHz}$ microwave radiation. Mutat. Res. 2005, 582, 42-52. [CrossRef] [PubMed]

59. Canseven, A.G.; Esmekaya, M.A.; Kayhan, H.; Tuysuz, M.Z.; Seyhan, N. Effects of microwave exposure and Gemcitabine treatment on apoptotic activity in Burkitt's lymphoma (Raji) cells. Electromagn. Biol. Med. 2015, 1-5. [CrossRef] [PubMed] 
60. Lee, S.; Johnson, D.; Dunbar, K.; Dong, H.; Ge, X.; Kim, Y.C.; Wing, C.; Jayathilaka, N.; Emmanuel, N.; Zhou, C.Q.; et al. $2.45 \mathrm{GHz}$ radiofrequency fields alter gene expression in cultured human cells. FEBS Lett. 2005, 579, 4829-4836. [CrossRef] [PubMed]

61. Sannino, A.; Zeni, O.; Romeo, S.; Massa, R.; Gialanella, G.; Grossi, G.; Manti, L.; Vijayalaxmi; Scarfi, M.R. Adaptive response in human blood lymphocytes exposed to non-ionizing radiofrequency fields: Resistance to ionizing radiation-induced damage. J. Radiat. Res. 2014, 55, 210-217. [CrossRef] [PubMed]

62. Zuo, H.Y.; Lin, T.; Wang, D.W.; Peng, R.Y.; Wang, S.M.; Gao, Y.B.; Xu, X.P.; Li, Y.; Wang, S.X.; Zhao, L.; et al. Neural cell apoptosis induced by microwave exposure through mitochondria-dependent caspase-3 pathway. Int. J. Med. Sci. 2014, 11, 426-435. [CrossRef] [PubMed]

63. Cao, Y.; Zhang, W.; Lu, M.X.; Xu, Q.; Meng, Q.Q.; Nie, J.H.; Tong, J. 900-MHz microwave radiation enhances gamma-ray adverse effects on SHG44 cells. J. Toxicol. Environ. Health A 2009, 72, 727-732. [CrossRef] [PubMed]

64. Lee, J.J.; Kwak, H.J.; Lee, Y.M.; Lee, J.W.; Park, M.J.; Ko, Y.G.; Choi, H.D.; Kim, N.; Pack, J.K.; Hong, S.I.; et al. Acute radio frequency irradiation does not affect cell cycle, cellular migration, and invasion. Bioelectromagnetics 2008, 29, 615-625. [CrossRef] [PubMed]

65. Scarfi, M.R.; Fresegna, A.M.; Villani, P.; Pinto, R.; Marino, C.; Sarti, M.; Altavista, P.; Sannino, A.; Lovisolo, G.A. Exposure to radiofrequency radiation ( $900 \mathrm{MHz}, \mathrm{GSM}$ signal) does not affect micronucleus frequency and cell proliferation in human peripheral blood lymphocytes: An interlaboratory study. Radiat. Res. 2006, 165, 655-663.

66. Capri, M.; Scarcella, E.; Fumelli, C.; Bianchi, E.; Salvioli, S.; Mesirca, P.; Agostini, C.; Antolini, A.; Schiavoni, A.; Castellani, G.; et al. In vitro exposure of human lymphocytes to $900 \mathrm{MHz}$ CW and GSM modulated radiofrequency: Studies of proliferation, apoptosis and mitochondrial membrane potential. Radiat Res. 2004, 162, 211-218. [CrossRef] [PubMed]

67. Lee, K.Y.; Kim, B.C.; Han, N.K.; Lee, Y.S.; Kim, T.; Yun, J.H.; Kim, N.; Pack, J.K.; Lee, J.S. Effects of combined radiofrequency radiation exposure on the cell cycle and its regulatory proteins. Bioelectromagnetics 2011, 32, 169-178. [CrossRef] [PubMed]

68. Schrader, T.; Munter, K.; Kleine-Ostmann, T.; Schmid, E. Spindle disturbances in human-hamster hybrid $\left(A_{L}\right)$ cells induced by mobile communication frequency range signals. Bioelectromagnetics 2008, 29, 626-639. [CrossRef] [PubMed]

69. Caraglia, M.; Marra, M.; Mancinelli, F.; D'Ambrosio, G.; Massa, R.; Giordano, A.; Budillon, A.; Abbruzzese, A.; Bismuto, E. Electromagnetic fields at mobile phone frequency induce apoptosis and inactivation of the multi-chaperone complex in human epidermoid cancer cells. J. Cell. Physiol. 2005, 204, 539-548. [CrossRef] [PubMed]

70. Lee, S.S.; Kim, H.R.; Kim, M.S.; Park, S.; Yoon, E.S.; Park, S.H.; Kim, D.W. Influence of smartphone Wi-Fi signals on adipose-derived stem cells. J. Craniofac. Surg. 2014, 25, 1902-1907. [CrossRef] [PubMed]

71. Schrader, T.; Kleine-Ostmann, T.; Munter, K.; Jastrow, C.; Schmid, E. Spindle disturbances in human-hamster hybrid $\left(A_{L}\right)$ cells induced by the electrical component of the mobile communication frequency range signal. Bioelectromagnetics 2011, 32, 291-301. [CrossRef] [PubMed]

72. Chauhan, V.; Mariampillai, A.; Kutzner, B.C.; Wilkins, R.C.; Ferrarotto, C.; Bellier, P.V.; Marro, L.; Gajda, G.B.; Lemay, E.; Thansandote, A.; et al. Evaluating the biological effects of intermittent $1.9 \mathrm{GHz}$ pulse-modulated radiofrequency fields in a series of human-derived cell lines. Radiat. Res. 2007, 167, 87-93. [CrossRef] [PubMed]

73. Liu, M.L.; Wen, J.Q.; Fan, Y.B. Potential protection of green tea polyphenols against $1800 \mathrm{MHz}$ electromagnetic radiation-induced injury on rat cortical neurons. Neurotoxic. Res. 2011, 20, 270-276. [CrossRef] [PubMed]

74. Sekijima, M.; Takeda, H.; Yasunaga, K.; Sakuma, N.; Hirose, H.; Nojima, T.; Miyakoshi, J. 2-GHz band CW and W-CDMA modulated radiofrequency fields have no significant effect on cell proliferation and gene expression profile in human cells. J. Radiat. Res. 2010, 51, 277-284. [CrossRef] [PubMed]

75. Chen, C.; Ma, Q.; Liu, C.; Deng, P.; Zhu, G.; Zhang, L.; He, M.; Lu, Y.; Duan, W.; Pei, L.; et al. Exposure to $1800 \mathrm{MHz}$ radiofrequency radiation impairs neurite outgrowth of embryonic neural stem cells. Sci. Rep. 2014, 4, 5103. [CrossRef] [PubMed]

76. Liu, Y.X.; Tai, J.L.; Li, G.Q.; Zhang, Z.W.; Xue, J.H.; Liu, H.S.; Zhu, H.; Cheng, J.D.; Liu, Y.L.; Li, A.M.; et al. Exposure to 1950-MHz TD-SCDMA electromagnetic fields affects the apoptosis of astrocytes via caspase-3-dependent pathway. PLoS ONE 2012. [CrossRef] [PubMed] 
77. Stagg, R.B.; Thomas, W.J.; Jones, R.A.; Adey, W.R. DNA synthesis and cell proliferation in C6 glioma and primary glial cells exposed to a $836.55 \mathrm{MHz}$ modulated radiofrequency field. Bioelectromagnetics 1997, 18, 230-236. [CrossRef]

78. Cleary, S.F.; Cao, G.; Liu, L.M. Effects of isothermal $2.45 \mathrm{GHz}$ microwave radiation on the mammalian cell cycle: Comparison with effects of isothermal $27 \mathrm{MHz}$ radiofrequency radiation exposure. Bioelectrochem. Bioenerg. 1996, 39, 167-173. [CrossRef]

79. Liu, K.; Zhang, G.; Wang, Z.; Liu, Y.; Dong, J.; Dong, X.; Liu, J.; Cao, J.; Ao, L.; Zhang, S. The protective effect of autophagy on mouse spermatocyte derived cells exposure to $1800 \mathrm{MHz}$ radiofrequency electromagnetic radiation. Toxicol. Lett. 2014, 228, 216-224. [CrossRef] [PubMed]

80. Szabo, I.; Rojavin, M.A.; Rogers, T.J.; Ziskin, M.C. Reactions of keratinocytes to in vitro millimeter wave exposure. Bioelectromagnetics 2001, 22, 358-364. [CrossRef] [PubMed]

81. Czyz, J.; Guan, K.; Zeng, Q.; Nikolova, T.; Meister, A.; Schonborn, F.; Schuderer, J.; Kuster, N.; Wobus, A.M. High frequency electromagnetic fields (GSM signals) affect gene expression levels in tumor suppressor P53-deficient embryonic stem cells. Bioelectromagnetics 2004, 25, 296-307. [CrossRef] [PubMed]

82. Lixia, S.; Yao, K.; Kaijun, W.; Deqiang, L.; Huajun, H.; Xiangwei, G.; Baohong, W.; Wei, Z.; Jianling, L.; Wei, W. Effects of $1.8 \mathrm{GHz}$ radiofrequency field on DNA damage and expression of heat shock protein 70 in human lens epithelial cells. Mutat. Res. 2006, 602, 135-142. [CrossRef] [PubMed]

83. Takashima, Y.; Hirose, H.; Koyama, S.; Suzuki, Y.; Taki, M.; Miyakoshi, J. Effects of continuous and intermittent exposure to RF fields with a wide range of SARs on cell growth, survival, and cell cycle distribution. Bioelectromagnetics 2006, 27, 392-400. [CrossRef] [PubMed]

84. Del Vecchio, G.; Giuliani, A.; Fernandez, M.; Mesirca, P.; Bersani, F.; Pinto, R.; Ardoino, L.; Lovisolo, G.A.; Giardino, L.; Calza, L. Effect of radiofrequency electromagnetic field exposure on in vitro models of neurodegenerative disease. Bioelectromagnetics 2009, 30, 564-572. [CrossRef] [PubMed]

85. Lu, Y.S.; Huang, B.T.; Huang, Y.X. Reactive oxygen species formation and apoptosis in human peripheral blood mononuclear cell induced by $900 \mathrm{MHz}$ mobile phone radiation. Oxid. Med. Cell. Longevity 2012. [CrossRef] [PubMed]

86. Terro, F.; Magnaudeix, A.; Crochetet, M.; Martin, L.; Bourthoumieu, S.; Wilson, C.M.; Yardin, C.; Leveque, P. GSM-900 MHz at low dose temperature-dependently downregulates alpha-synuclein in cultured cerebral cells independently of chaperone-mediated-autophagy. Toxicology 2012, 292, 136-144. [CrossRef] [PubMed]

87. Duranti, G.; Rossi, A.; Rosato, N.; Fazio, G.; Sacerdoti, G.; Rossi, P.; Falsaperla, R.; Cannelli, V.; Supino, R. In vitro evaluation of biological effects on human keratinocytes exposed to $900 \mathrm{MHz}$ electromagnetic field. Environmentalist 2005, 25, 113-119. [CrossRef]

88. Maes, A.; Collier, M.; Slaets, D.; Verschaeve, L. $954 \mathrm{MHz}$ microwaves enhance the mutagenic properties of mitomycin C. Environ. Mol. Mutagen. 1996, 28, 26-30. [CrossRef]

89. Trillo, M.A.; Cid, M.A.; Martinez, M.A.; Page, J.E.; Esteban, J.; Ubeda, A. Cytostatic response of NB69 cells to weak pulse-modulated 2.2 GHz radar-like signals. Bioelectromagnetics 2011, 32, 340-350. [CrossRef] [PubMed]

90. Esmekaya, M.A.; Aytekin, E.; Ozgur, E.; Guler, G.; Ergun, M.A.; Omeroglu, S.; Seyhan, N. Mutagenic and morphologic impacts of $1.8 \mathrm{GHz}$ radiofrequency radiation on human peripheral blood lymphocytes (hPBLs) and possible protective role of pre-treatment with ginkgo biloba (EGB 761). Sci. Total Environ. 2011, 410-411, 59-64. [CrossRef] [PubMed]

91. Maioli, M.; Rinaldi, S.; Santaniello, S.; Castagna, A.; Pigliaru, G.; Gualini, S.; Cavallini, C.; Fontani, V.; Ventura, C. Radio electric conveyed fields directly reprogram human dermal skin fibroblasts toward cardiac, neuronal, and skeletal muscle-like lineages. Cell. Transplant. 2013, 22, 1227-1235. [CrossRef] [PubMed]

92. Velizarov, S.; Raskmark, P.; Kwee, S. The effects of radiofrequency fields on cell proliferation are non-thermal. Bioelectrochem. Bioenerg. 1999, 48, 177-180. [CrossRef]

93. Falzone, N.; Huyser, C.; Franken, D.R.; Leszczynski, D. Mobile phone radiation does not induce pro-apoptosis effects in human spermatozoa. Radiat. Res. 2010, 174, 169-176. [CrossRef] [PubMed]

94. Marinelli, F.; La Sala, D.; Cicciotti, G.; Cattini, L.; Trimarchi, C.; Putti, S.; Zamparelli, A.; Giuliani, L.; Tomassetti, G.; Cinti, C. Exposure to $900 \mathrm{MHz}$ electromagnetic field induces an unbalance between pro-apoptotic and pro-survival signals in T-lymphoblastoid leukemia CCRF-CEM cells. J. Cell. Physiol. 2004, 198, 324-332. [CrossRef] [PubMed] 
95. Vijayalaxmi; Mohan, N.; Meltz, M.L.; Wittler, M.A. Proliferation and cytogenetic studies in human blood lymphocytes exposed in vitro to $2450 \mathrm{MHz}$ radiofrequency radiation. Int. J. Radiat. Biol. 1997, 72, 751-757. [PubMed]

96. French, P.; Donnellan, M.; McKenzie, D.R. Electromagnetic radiation at $835 \mathrm{MHz}$ changes the morphology and inhibits proliferation of a human astrocytoma cell line. Bioelectrochem. Bioenerg. 1997, 43, 13-18. [CrossRef]

97. Merola, P.; Marino, C.; Lovisolo, G.A.; Pinto, R.; Laconi, C.; Negroni, A. Proliferation and apoptosis in a neuroblastoma cell line exposed to $900 \mathrm{MHz}$ modulated radiofrequency field. Bioelectromagnetics 2006, 27, 164-171. [CrossRef] [PubMed]

98. Vijayalaxmi; Bisht, K.S.; Pickard, W.F.; Meltz, M.L.; Roti Roti, J.L.; Moros, E.G. Chromosome damage and micronucleus formation in human blood lymphocytes exposed in vitro to radiofrequency radiation at a cellular telephone frequency (847.74 MHz, CDMA). Radiat. Res. 2001, 156, 430-432. [PubMed]

99. Gurisik, E.; Warton, K.; Martin, D.K.; Valenzuela, S.M. An in vitro study of the effects of exposure to a GSM signal in two human cell lines: Monocytic U937 and neuroblastoma SK-N-SH. Cell. Biol. Int. 2006, 30, 793-799. [CrossRef] [PubMed]

100. Miyakoshi, J.; Takemasa, K.; Takashima, Y.; Ding, G.R.; Hirose, H.; Koyama, S. Effects of exposure to a 1950 $\mathrm{MHz}$ radio frequency field on expression of Hsp70 and Hsp27 in human glioma cells. Bioelectromagnetics 2005, 26, 251-257. [CrossRef] [PubMed]

101. Vijayalaxmi; Leal, B.Z.; Meltz, M.L.; Pickard, W.F.; Bisht, K.S.; Roti Roti, J.L.; Straube, W.L.; Moros, E.G. Cytogenetic studies in human blood lymphocytes exposed in vitro to radiofrequency radiation at a cellular telephone frequency (835.62 MHz, FDMA). Radiat. Res. 2001, 155, 113-121. [PubMed]

102. Higashikubo, R.; Ragouzis, M.; Moros, E.G.; Straube, W.L.; Roti Roti, J.L. Radiofrequency electromagnetic fields do not alter the cell cycle progression of C3H 10T and U87MG cells. Radiat. Res. 2001, 156, 786-795. [CrossRef]

103. Moisescu, M.G.; Leveque, P.; Bertrand, J.R.; Kovacs, E.; Mir, L.M. Microscopic observation of living cells during their exposure to modulated electromagnetic fields. Bioelectrochemistry 2008, 74, 9-15. [CrossRef] [PubMed]

104. Vijayalaxmi; Reddy, A.B.; McKenzie, R.J.; McIntosh, R.L.; Prihoda, T.J.; Wood, A.W. Incidence of micronuclei in human peripheral blood lymphocytes exposed to modulated and unmodulated $2450 \mathrm{MHz}$ radiofrequency fields. Bioelectromagnetics 2013, 34, 542-548. [CrossRef] [PubMed]

105. Hintzsche, H.; Jastrow, C.; Kleine-Ostmann, T.; Karst, U.; Schrader, T.; Stopper, H. Terahertz electromagnetic fields $(0.106 \mathrm{THz})$ do not induce manifest genomic damage in vitro. PLoS ONE 2012. [CrossRef] [PubMed]

106. Moquet, J.; Ainsbury, E.; Bouffler, S.; Lloyd, D. Exposure to low level GSM $935 \mathrm{MHz}$ radiofrequency fields does not induce apoptosis in proliferating or differentiated murine neuroblastoma cells. Radiat. Prot. Dosim. 2008, 131, 287-296. [CrossRef] [PubMed]

107. Waldmann, P.; Bohnenberger, S.; Greinert, R.; Hermann-Then, B.; Heselich, A.; Klug, S.J.; Koenig, J.; Kuhr, K.; Kuster, N.; Merker, M.; et al. Influence of GSM signals on human peripheral lymphocytes: Study of genotoxicity. Radiat. Res. 2013, 179, 243-253. [CrossRef] [PubMed]

108. Hintzsche, H.; Jastrow, C.; Kleine-Ostmann, T.; Schrader, T.; Stopper, H. 900 MHz radiation does not induce micronucleus formation in different cell types. Mutagenesis 2012, 27, 477-483. [CrossRef] [PubMed]

109. Naziroglu, M.; Cig, B.; Dogan, S.; Uguz, A.C.; Dilek, S.; Faouzi, D. 2.45-Gz wireless devices induce oxidative stress and proliferation through cytosolic $\mathrm{Ca}^{2+}$ influx in human leukemia cancer cells. Int. J. Radiat. Biol. 2012, 88, 449-456. [CrossRef] [PubMed]

110. Wu, H.; Wang, D.; Shu, Z.; Zhou, H.; Zuo, H.; Wang, S.; Li, Y.; Xu, X.; Li, N.; Peng, R. Cytokines produced by microwave-radiated sertoli cells interfere with spermatogenesis in rat testis. Andrologia 2012. [CrossRef] [PubMed]

111. Hirose, H.; Sakuma, N.; Kaji, N.; Suhara, T.; Sekijima, M.; Nojima, T.; Miyakoshi, J. Phosphorylation and gene expression of P53 are not affected in human cells exposed to $2.1425 \mathrm{GHz}$ band $\mathrm{Cw}$ or W-CDMA modulated radiation allocated to mobile radio base stations. Bioelectromagnetics 2006, 27, 494-504. [CrossRef] [PubMed]

112. Nikolova, T.; Czyz, J.; Rolletschek, A.; Blyszczuk, P.; Fuchs, J.; Jovtchev, G.; Schuderer, J.; Kuster, N.; Wobus, A.M. Electromagnetic fields affect transcript levels of apoptosis-related genes in embryonic stem cell-derived neural progenitor cells. Faseb. J. 2005, 19, 1686-1688. [CrossRef] [PubMed] 
113. Xu, S.; Chen, G.; Chen, C.; Sun, C.; Zhang, D.; Murbach, M.; Kuster, N.; Zeng, Q.; Xu, Z. Cell type-dependent induction of DNA damage by $1800 \mathrm{MHz}$ radiofrequency electromagnetic fields does not result in significant cellular dysfunctions. PLoS ONE 2013. [CrossRef] [PubMed]

114. Hoyto, A.; Luukkonen, J.; Juutilainen, J.; Naarala, J. Proliferation, oxidative stress and cell death in cells exposed to $872 \mathrm{MHz}$ radiofrequency radiation and oxidants. Radiat. Res. 2008, 170, 235-243. [CrossRef] [PubMed]

115. Ozgur, E.; Guler, G.; Kismali, G.; Seyhan, N. Mobile phone radiation alters proliferation of hepatocarcinoma cells. Cell. Biochem. Biophys. 2014, 70, 983-991. [CrossRef] [PubMed]

116. Yang, L.; Hao, D.; Wang, M.; Zeng, Y.; Wu, S.; Zeng, Y. Cellular neoplastic transformation induced by $916 \mathrm{MHz}$ microwave radiation. Cell. Mol. Neurobiol. 2012, 32, 1039-1046. [CrossRef] [PubMed]

117. Hoyto, A.; Sokura, M.; Juutilainen, J.; Naarala, J. Radiofrequency radiation does not significantly affect ornithine decarboxylase activity, proliferation, or caspase-3 activity of fibroblasts in different physiological conditions. Int. J. Radiat. Biol. 2008, 84, 727-733. [CrossRef] [PubMed]

118. Pacini, S.; Ruggiero, M.; Sardi, I.; Aterini, S.; Gulisano, F.; Gulisano, M. Exposure to global system for mobile communication (GSM) cellular phone radiofrequency alters gene expression, proliferation, and morphology of human skin fibroblasts. Oncol. Res. 2002, 13, 19-24. [PubMed]

119. Yao, K.; Wang, K.J.; Sun, Z.H.; Tan, J.; Xu, W.; Zhu, L.J.; Lu, D.Q. Low power microwave radiation inhibits the proliferation of rabbit lens epithelial cells by upregulating P27Kip1 expression. Mol. Vis. 2004, 10, 138-143. [PubMed]

120. WHO. Health and Environmental Effects of Exposure to Static and Time Varying Electric and Magnetic Fields: Guidelines for Quality Research. Available online: http://apps.who.int/iris/bitstream/10665/ 64013/1/WHO_EHG_98.13.pdf (accessed on 10 February 2016).

121. Brazma, A.; Hingamp, P.; Quackenbush, J.; Sherlock, G.; Spellman, P.; Stoeckert, C.; Aach, J.; Ansorge, W.; Ball, C.A.; Causton, H.C.; et al. Minimum information about a microarray experiment (MIAME)—Toward standards for microarray data. Nat. Genet. 2001, 29, 365-371. [CrossRef] [PubMed]

(C) 2016 by the authors; licensee MDPI, Basel, Switzerland. This article is an open access article distributed under the terms and conditions of the Creative Commons Attribution (CC-BY) license (http://creativecommons.org/licenses/by/4.0/). 